\title{
TRANSFORMATION OF A VILLAGE: CASE OF WAD AL ABBAS, SENNAR STATE, SUDAN
}

\author{
Muhagir Elkamali and M. M. Yagoub* \\ Department of Geography and Urban Sustainability, College of Humanities and Social Sciences, United Arab Emirates \\ University, Al Ain, UAE - (201890072, myagoub)@uaeu.ac.ae
}

KEYWORDS: Village transformation, remote sensing, Object-Based Image Analysis (OBIA)

\begin{abstract}
:
Understanding socioeconomic changes associated with the conversion of rural areas to urban and the factors behind them are essential for future prospects. Theoretical debates on the topic have flourished. However, empirical case studies, particularly from developing nations, are limited. This study attempts to fill the gap through a case study of a village in Sudan. The development of Wad al Abbas village is investigated using remote sensing techniques employing free Landsat satellite images. The study used the Object-Based Image Analysis (OBIA) approach to detect the village sprawl between 1987 and 2018. Results showed significant built-up growth (84.5\% increase) between 1987 and 1998 and this is linked to the natural increase in population, diversification of income as a result of a change in jobs from farming to trade, migration of a large number of its residents in and outside the country, and attraction of administrative and governmental institutions. Although Wad al Abbas starts to have a town feature in terms of population size and other metrics, still there are many challenges facing this transformation. These include water, education, health, sewage system, solid waste, drainage system, landslide, water channel for the agricultural scheme (canal), the meandering of the Blue Nile, and inner road network. High-resolution satellite images could be used to help in the investigation of these challenges. Recommendations are made on how to deal with these challenges. The lesson learned from this study is the value of the use of the space (free satellite images) to document changes that couldn't be monitored especially in developing countries where historical maps or aerial photographs are not available.
\end{abstract}

\section{INTRODUCTION}

Sprawl is one of the global phenomena that leads to a change in landscape nature. Urban or rural sprawl can be defined as the process of spilling-over settlement areas and of excessive use of the open landscape by an unsystematic, mostly weak condensed extension of settlement areas in the fringe of urban agglomeration. The global percentage of the population in urban areas is more than $50 \%$ and it is expected to reach $70 \%$ in 2030 (Gao et al., 2017). This movement towards urbanization is expected to occur more in developing countries where the basic infrastructure is not sufficient, particularly in rural areas. The most important characteristic of urban/rural sprawl is that it occurs irregularly and without planning, it happens according to many processes and factors. Mapping urban/rural sprawl becomes important for many applications, such as land-use planning, environmental sciences, natural sciences, and protecting the environmental and natural resources against any possible threats. The most effective way to observe the urban/rural sprawl is through monitoring land use/land cover changes.

The rapid development of remote sensing provides a powerful tool for land use land cover monitoring in a cost-effective way. In recent years, many remote sensing satellites launched with different missions. The valuable data from space makes the land use/land cover monitoring more effective. Urban/rural sprawl is unplanned but still, it is anthropogenic activities, remote sensing has the capabilities to recognize human activities through space and time. Remote sensing technology relies on image resolutions (spatial, spectral, temporal, and radiometric). Land use land cover is generated from remote sensing images through the classification of spectral information for a specific area. Object-
Based Image Analysis (OBIA) classification method is recently used by various researchers to study urban/rural sprawl (Yan et al., 2006; Whiteside et al., 2011; Kar et al., 2018). OBIA technique takes into account not just the spectral information of the pixel, but also the object geometry from surrounded pixels. Many researchers used remote sensing images to study the change in rural and urban areas. For example, Yagoub (2004) used aerial photographs and satellite images to identify the transformation of Al Ain city in the United Arab Emirates (UAE). Suja et al. (2013) investigated the transformation of Kerala (India) using urban indices such as Urbanization Intensity Index (UII) and Urbanization Proportion Index (UPI). Fichera et al. (2011) studied the urban-rural transformation in an area over Avellino province in the Campania region in Italy for fifty years (1954-2004). They used digital aerial orthophotos and Landsat images to generate land use land cover maps for different periods within the study time. Four classes were found from the classification process using the maximum likelihood algorithm, those classes are urban, woodland, cropland, and grassland/pasture. A study of spatio-temporal dynamics of the urban landscape of Nagpur city, Central India for the period 1936-2010 utilized maps on 1:50,000 scale for 1936 and 1976 and Landsat 5 satellite images for 1991 and 2010 (Kar et al., 2018). The study created land use land cover maps using visual interpretation from the maps and Object Image-Based Analysis (OBIA) for satellite images, then a comparison between these maps was performed to compute the urban/rural sprawl. This indicates that in the absence of satellite images, topographic maps could be used to fill the gap.

\footnotetext{
* Corresponding author
} 
The objective of this study is to investigate the transformation of Wad al Abbas village (countryside) in Sennar State, Sudan from satellite images using the Object-Based Image Analysis (OBIA) technique and link this transformation to socio-economic factors. Moreover, the study addressed the challenges that face the village transformation and suggestions were made on how to go around these challenges.

\section{DATA \& STUDY AREA}

Wad al Abbas (the study area) is located between latitude $13^{\circ} 44^{\prime}$ $21.12^{\prime \prime}$ and $13^{\circ} 47^{\prime} 34.02^{\prime \prime}$ North and longitude $33^{\circ} 36^{\prime} 35.6^{\prime \prime}$ and $33^{\circ} 39^{\prime} 54.63^{\prime \prime}$ East on the eastern bank of the Blue Nile river (Figure 1). The main land-use types in Wad al Abbas include built-up, agriculture in the east of the village, and water (Blue Nile) in the west (Figure 1). This study focuses on built-up areas only.

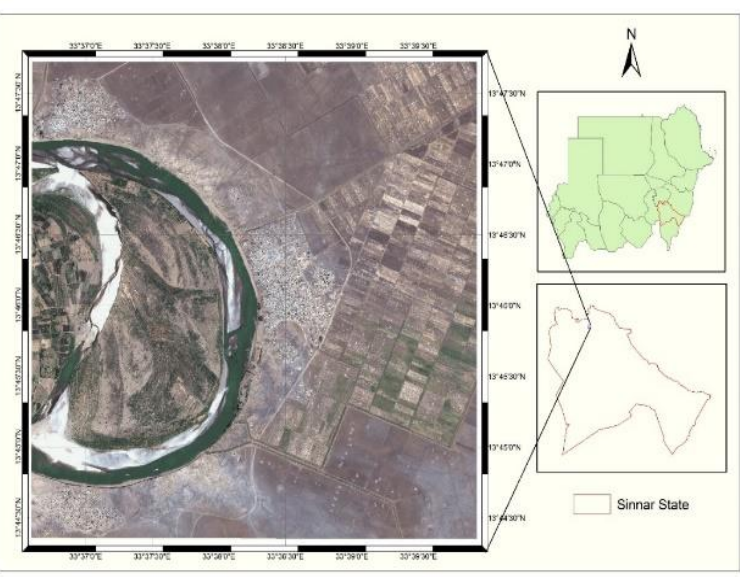

Figure 1. The location of the study area (Wad Alabas village).

Data used to map the village expansion for the period (19872018) were Landsat satellite images downloaded from the United States Geological Survey (USGS) Earth Explorer website (https://earthexplorer.usgs.gov/). The selection of the images is based on availability, a span of a 10-year period, and be cloudfree (Table 1). In order to quantify the built-up areas accurately, Google Earth data were used to exclude non-built-up areas inside the village boundary. Furthermore, the historical data from Google Earth were used to evaluate the built-up areas extracted from image processing.

\begin{tabular}{|l|l|l|}
\hline Date & Satellite & Sensor \\
\hline $3 / 6 / 1987$ & Landsat 5 & TM \\
\hline $11 / 6 / 1998$ & Landsat 5 & TM \\
\hline $6 / 6 / 2008$ & Landsat 5 & TM \\
\hline $2 / 6 / 2018$ & Landsat 8 & OLI \\
\hline
\end{tabular}

Table 1. Landsat satellite images data

\section{METHODOLOGY}

The Landsat data were analyzed using the Environment for Visualizing Images (ENVI) image processing software to extract built-up areas. The satellite images were prepared in order to perform the Object-Based Image Analysis algorithm (OBIA). The preparation process (pre-process) consisted of registration, subset, and atmospheric correction. The four Landsat images were registered using pixel-by-pixel based to overcome the orbital change and emphasize the overlapping images for change detection analysis. Subset images were created for spatial component and the Visible, Near Infrared (NIR), and Short-Wave Infrared (SWIR) bands for a spectral component. The atmospheric correction has been applied to the images via QUick Atmospheric Correction (QUAC) tool in order to remove the atmosphere contributions.

OBIA is a classification approach based on the image objects characteristics like shape, tone, and texture instead of pixel-based classification approach. OBIA dividing the image into small objects where each object consists of a group of pixels with similar characteristics (Jensen, 2016). OBIA was performed to extract the built-up areas from the four images. In order to monitor the change in built-up areas, the cemetery area was digitized from Google Earth and imported to a geodatabase. This area was excluded to produce only the built-up areas. The area for each year is calculated along with the growth percentage between every two successive dates. The extracted built-up areas were checked with Google Earth's image for quality assurance/quality control (Hegde and Hegde 2007).

\section{RESULTS}

Wad al Abbas had seen a big increase (84.51\%) in the built-up area during 1987-1998 (Table 2). Between 1998 and 2018 it had seen an increase ranges between 19 to $29 \%$ (Table 2, Figure 2). The drop-in built-up area rate of growth after 1998 happened because of the sharp decline in the economy of the country due to the economic sanctions imposed by the international community (e.g. by the USA). This led to inflation and a significant increase in land value, house prices, construction material, and labour payment.

The overall increase in a built-up area between 1987 and 2018 is due to many factors such as an increase in population, improvement in income, and attraction of administrative institutions. The population of Wad al Abbas was about fivethousand in the early $1990 \mathrm{~s}$ and it is 10,000 according to estimation in 2010 with an average annual increase of $5 \%$. The total population of Sudan is 43,081,928 as reported by the World Population Review (2019) and World meters, 2019. The annual population increase in Wad al Abbas is considered high in comparison to Sudan's annual urban population growth (2.97\%) and the rural population growth $(2.08 \%)$ (Trading Economics, 2019). This is due to the increase in birth rate and migration. Migration is the movement of people in space, often involving a change in the usual place of residence; internal migration is such a movement within national boundaries. "In-migration" here refers to the attraction of the people to the village while "outmigration" refers to the people leaving the village. Wad al Abbas has seen in and out-migration. One of the pulling factors for the in-migration is the agricultural scheme, where it attracted a large number of officers and workers together with their families. The agricultural scheme supports almost $80 \%$ of the population in the village. Other factors include an increase in the number of educational facilities such as more schools and the college of public health. The paved road that links the village to Sennar city is expected to attract more people.

On the other hand, the village has seen outmigration (internal/domestic migration within the country, rural to urban) for various reasons. These reasons fall within the general frame of searching for job opportunities, better education, better health or care-related reasons, housing and neighbourhood issues, climate change, technology, competition and unequal distribution of government power and funds (DarlingtonPollock et al., 2018; Newbold, 2009; Singh, 2019; Vago, 2003). 
The rural-urban movement, whether circulation and for a temporary stay in town or for permanent urban residence, is by far the most significant form of movement for the long-term trend of spatial redistribution (Oucho, 1981). For example, between 2001 and 2011, 8.1 million farmers in India have left agriculture due to an interplay of increasing climate variability, environmental change, rural debt, and policy shifts (Krishna et al., 2014). A similar situation is observed in Wad al Abbas where agriculture (the main job) is facing pressure from land degradation, low and stagnant yields, and frequent price fluctuations (laborious and unprofitable agriculture). No Wad al Abbas household lives by farming alone, and villagers engage in various types of nonfarm work (Bernal, 1994). Other job opportunities in Wad al Abbas are in schools, municipality, police, health facilities, trading (livestock, vegetables, meat, clothes and other consuming goods). During the 1970's and 1980 's majority of the people in the village worked in farming (Blue Nile Scheme) and livestock, after that the number of people involves in farming has seen a continuous decline due to low returns from agriculture (low yields and more tax by the government). By the early 1980s, only about one in four Wad al Abbas men was a farmer (Bernal, 1994). Nowadays it is less than that and the majority of households used hired farm labour just to hold their lands. In fact, returns from agriculture in Wad al Abbas are extremely low and become not attractive ventures (Bernal, 1994). Generally, outmigration causes diversity in income (Chami et al., 2003; Ratha, 2007). Income increase happened in Wad al Abbas due to change in jobs where many farmers moved to trade in other cities with more population and more purchasing power while other people migrate to the wealthy Gulf countries. The majority of those who migrated from the village is on a temporary basis and normally send money back (remittances) for building houses, supporting families and supporting public facilities in the village. This led to an increase in the number and quality of buildings and hence development. About $80 \%$ of people who migrated outside the village are in the working-age group (15-64) educated males seeking job opportunities. No statistics about the number of people who migrated outside the village. A rough estimation indicates that Khartoum, the capital of Sudan, is the favourite destination. Other cities that attract people from the village include Al Damazin, Al Obaid, and Port Sudan. The migration from the village to other countries has seen a steady increase since the 1990 s with the majority migrated to Saudi Arabia. This is in line with the global migration pattern where in 2017 some 258 million people or 3.4 percent of the world's population are believed to live outside their countries of birth (United Nations, 2019).

\begin{tabular}{|c|c|c|}
\hline Year & Area $\left(\mathrm{km}^{2}\right)$ & $\begin{array}{c}\text { Percentage of } \\
\text { Growth }\end{array}$ \\
\hline 1987 & 0.536022 & - \\
\hline 1998 & 0.988995 & 84.51 \\
\hline 2008 & 1.181075 & 19.42 \\
\hline 2018 & 1.525668 & 29.18 \\
\hline
\end{tabular}

Table 2. Change in the total built-up areas in Wad al Abbas between 1987 and 2018

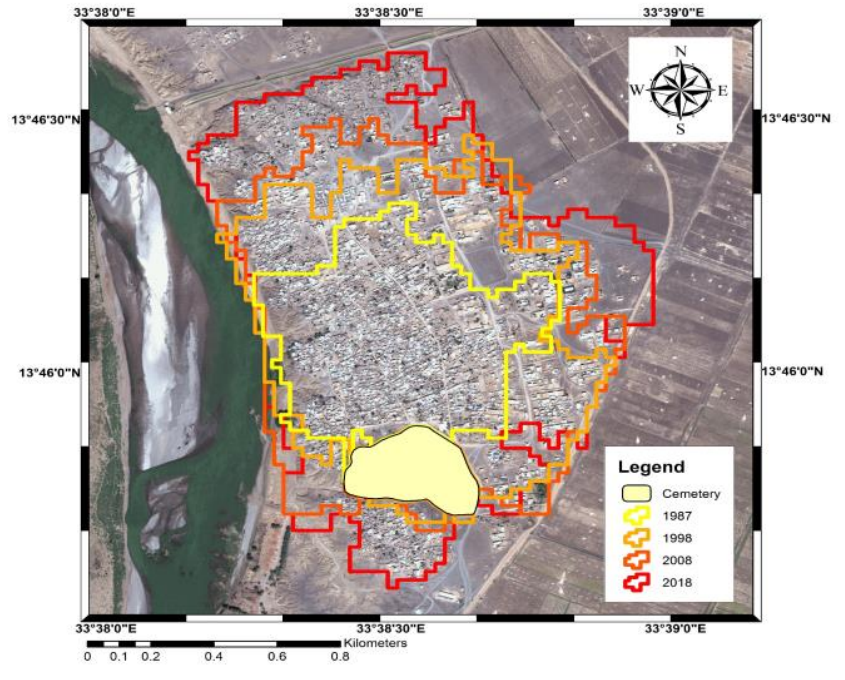

Figure 2. Expansion of built-up areas between 1987 and 2018.

\section{CHALLENGES AND WAYS AROUND}

Wad al Abbas faces many challenges such as availability of water, education, health, sewage system, solid waste, drainage system, landslide, water channel for the agricultural scheme (canal), the meandering of the Blue Nile, and inner road network. High-resolution satellite images could be used to help in the investigation of these challenges.

The majority of the people in the village depend on groundwater (six water wells) for drinking. The use of Blue Nile water for drinking has seen a continuous decline due to biological/ microbial/ pathogens, chemicals, and sediments, discharge from factories, pesticides, and insecticides. However, it is used as a backup in case of a shortage from the wells. It is recommended to establish a backup treatment plant and ensure that water meets the World Health Organization (WHO) guidelines/standards for drinking-water (WHO, 2017). At the family level, filters and boiling of water could be used to reduce the risk. It is important that the water quality to be monitored continuously and public awareness and educational programs to be implemented to ensure that the community is aware of the importance of drinking-water quality and its relationship with health.

Education in Wad al Abbas consists of six primary schools, two secondary schools, and a public health college. Elementary education in Wad al Abbas started in 1957. In the school year $2016 / 2017$, the total number of students in primary schools was 2440 with $65.8 \%$ are females. The total number of students in the two secondary schools was 500 with $54 \%$ are females. It is very clear that there is a gender gap in primary school enrolment. The gender parity index (GPI) (ratio of female to male values) (UNSECO, 2019) at the village is 1.93 indicating a disparity in favour of girls. According to the UNICEF, two-thirds of countries have reached gender parity value between 0.97 and 1.03 in enrolment in primary education, but in countries that have not reached parity, particularly in Sub-Saharan Africa, the Middle East, and South Asia, girls are more likely to be disadvantaged than boys (the GPI value is 0.77) (UNICEF, 2019). Although there is no data about the birth rate for males/females, it seems that more girls are joining primary schools. This may be due to the fact that male children drop out of school to work in order to help their families. More data is needed to understand the situation. Comparing GPI at primary 
schools (1.93) and at secondary schools (1.17) indicates that a large portion of females do not get chances to enrol at secondary schools. The reason for this is the limited number of public high schools (only two). It is recommended to add more high schools even on a private basis and establish a vocational training institute that can attract more students. The quality of education in Wad al Abbas decreases gradually due to migration of qualified teachers and educational environment (buildings, chairs, classes, landscape).

The health facilities in the village includes one public hospital and it lacks staff and equipment. Doctors migrate to other cities and abroad for better opportunities (higher income, continuing education, etc.). The deterioration of the public health facilities lead to the rise of private clinics. It is expected that this will result in privatization of the health sector and this is a challenge for lowincome people. The creation of the online (WhatsApp) group in 2019 (more than 200 members) to raise funds for deprived patients in the village will play an important role in facing the privatization of the healthcare.

The current practice of the sewage system in the village is based on septic tanks drain to effluent disposal wells (onsite sewage facility). The average depth of effluent disposal wells in the village is 20 meter while the drinking wells are at an average depth of 100 meter. Preliminary assessment of drinking water in village showed degradation of water quality. However, it becomes necessary to carry out detailed investigation on impact of effluent disposal wells and decay of pipelines on water quality as this has a direct impact on human health. Construction of septic tanks and wells inside buildings need to follow standards/specifications (e.g. depth of the borehole, diameter, depth of groundwater in the site, casing material, site conditions, etc.) when issuing building permits.

There is no artificial drainage system in the village. Normally rain drained through natural storm-water system (Khors) following the slopes toward the Blue Nile. The increase in builtup areas, increases impervious surface areas inside buildings, and dumping of waste, block the natural movement of water and consequently lead to flooding in many parts of the village and in turn spread of mosquitos. To avoid this problem and reduce its impact, it is recommended to install pipes with manholes in existing storm water drains. Harvesting rainwater from roofs by families through pipes to water tanks could be an option.

Historically landslide (soil erosion and movement of earth caused by rain) forced many families to shift their houses to new locations. The soil in the village is dominated by the clay type that is easily eroded by heavy rains and lead to landslide near the Blue Nile bank and this endangered many houses. Plantation of trees/shrubs, adding rocks on top of soil, using matting to hold vegetation on slope, putting down of fibre logs, and improvement of drainage system could help in reducing soil erosion (Wikihow, 2019).

The new water canal for the agricultural scheme was established in 2015-2016. The canal originated at Maina south of Sennar dam with the intention of getting use of Sennar dam storage lake throughout the year. It passes at the eastern part of the village from south to north and has advantages and disadvantages. The advantages include availability of more water for irrigation than previous and consequently more cultivation per year and this resulted in increase of income. The canal represents an artificial barrier for water drained from the agricultural scheme and hence reduce the probability of flooding of the village. The disadvantages include limiting future expansion of the village in the eastern part. This is the only direction where the village can expand because on the west it is surrounded by the Blue Nile and on the north and south has limited vacant land. Leakage or unexpected break of the canal as happened in October, 2019 may result in flooding of the village. In addition to that, the water in the canal may result in attraction of mosquitos and causes spread of mosquito-borne diseases such as malaria.

Among the options that could be used to reduce the adverse effect of the canal include strengthening the canal part especially that facing the village, planting of trees along the canal to stabilize the soil, cleaning the canal continuously, real time monitoring of mosquitos and diversion of the canal for few kilometres towards the east.

Other challenge that faced the village is the meandering of the Blue Nile. The flow of the Blue Nile reflects the seasonality of rainfall over the Ethiopian highlands where the two flow periods are distinct. The flood period or wet season extends from July to October and low flow or dry season from November to June (FAO, 2019). The Blue Nile accounts for $85 \%$ of the Nile water. There is no record of flooding of the village from Blue Nile and this is due to its location on high land. However, the continuous change in the course of the Blue Nile (meandering) due to sediments deposition may represent a problem. The building of the Grand Ethiopian Renaissance Dam which is planned to be completed by 2020 and fill a large reservoir ( 74 billion cubic meters) may have an impact on the amount of sediments deposition. A study conducted by Zhang et al. (2015) showed that there will be reduction in streamflow entering Sudan. A study by Ghosh and Sahu (2019) on river Ganga-Bhagirathi in India shows that an area with active bank erosion problem is characterized by remarkable land use land cover changes. It is recommended to increase the plantation along the Blue Nile bank that faces the village, fill low areas (embankment), and minimize new buildings near the river bank.

Inner road network in the village is becoming a problem that faced transportation movement. Large portion of the village (more than 60\%) is unplanned and there is a continuous encroachment by people on both sides of the roads. This situation is evident also in the planned part of the village. Therefore, public awareness is needed coupled with implementation of planning policies and rules.

\section{CONCLUSION}

This study demonstrates how space technology can provide a cost-effective tool for land cover/land use change monitoring. Transformation of Wad al Abbas is documented using remotely sensed data with image processing. Major expansion found in the period between 1987 and 1998 with $84.5 \%$ of built-up growth. Using medium resolution satellite as Landsat to monitor land cover changes in small area have limitations due to it is spatial resolution that makes it less appropriate for many applications. Future studies need high-resolution images to overcome this limitation and provide high accurate change detection. Wad al Abbas faces problems in water, education, health, sewage system, solid waste, drainage system, landslide, water channel for agricultural scheme (canal), meandering of the Blue Nile and inner road network. With less support from the central government to public facilities, Wad al Abbas could overcome the challenges through non-governmental organizations and cooperation of its people.

\section{ACKNOWLEDGMENTS}

The United Arab Emirates University is gratefully acknowledged for offering $\mathrm{PhD}$ scholarship for Mr. Muhagir Elkamali. The authors would like to acknowledge the United States Geological Survey (USGS) for providing free satellite images. Gratitude is extended to Prof. Bernal, V and Khalid Hussein for editing the article and constructive comments and suggestions. 


\section{AUTHOR CONTRIBUTIONS}

Conceptualization: M. M. Yagoub and Muhagir Elkamali; Data curation: Muhagir Elkamali; Formal analysis: Muhagir Elkamali and M. M. Yagoub; Methodology: Muhagir Elkamali; Supervision: M. M. Yagoub; Writing: M. M. Yagoub and Muhagir Elkamali.

\section{REFERENCES}

Bernal, V., 1994. Peasants, capitalism, and (ir)rationality. American Ethnologist,21(4), 792-810 doi:10.1525/ae.1994.21.4.02a00070.

Chami, R., C. Fullenkamp, \& S. Jahjah, 2003. Are Immigrant Remittance Flows a Source of Capital for Development. IMF Working Paper Series, WP/03/189, IMF.

Darlington- Pollock, F., Lomax, N., \& Norman, P., 2018. Ethnic internal migration: The importance of age and migrant status. The Geographical Journal, 185(1), 68 - 81. Doi: 10.1111/geoj.12286.

Food and Agricultural Organization (FAO), 2019. Sudan Geography, climate and population. http://www.fao.org/nr/water/aquastat/countries_regions/SD N/print1.stm (accessed on 6 October, 2019).

Fichera, C. R., Modica, G., \& Pollino, M., 2011. GIS and Remote Sensing to Study Urban-Rural Transformation During a Fifty-Year Period. Computational Science and Its Applications - ICCSA 2011 Lecture Notes in Computer Science, 237-252. doi:10.1007/978-3-642-21928-3_17

Gao, Z., Kii, M., Nonomura, A., Nakamura, K., 2017. Urban expansion using remote-sensing data and a monocentric urban model. Computers, Environment and Urban Systems. Doi: 10.1016/j.compenvurbsys.2017.05.002.

Ghosh, D. \& Sahu, A.S. J., 2019. Bank Line Migration and Its Impact on Land Use and Land Cover Change: A Case Study in Jangipur Subdivision of Murshidabad District, West Bengal. Journal of the Indian Society of Remote Sensing (2019) 47: 1969. https://doi.org/10.1007/s12524-01901043-0.

Hegde NP, and Hegde GL, 2007. Quality control in large spatial databases maintenance. 5th International Symposium for Spatial Data Quality. ITC, Enschede, p 3

Jensen, J. R., 2016. Introductory digital image processing: A remote sensing perspective. Glenview: Pearson Education.

Kar, R., Reddy, G. O., Kumar, N., \& Singh, S., 2018. Monitoring spatio-temporal dynamics of urban and peri-urban landscape using remote sensing and GIS - A case study from Central India. The Egyptian Journal of Remote Sensing and Space Science. doi: 10.1016/j.ejrs.2017.12.006.

Krishna, A., Sriram, M. S., \& Prakash, P., 2014. Slum types and adaptation strategies: Identifying policy- relevant differences in Bangalore. Environment and Urbanization, 26, 568-585. https://doi.org/10.1177/0956247814537958

Newbold, K. B., 2009. Population geography: Tools and issues. Lanham: Rowman \& Littlefield.

Oucho, J.O., 1981. Rural-rural migration and population change. A study of the Kericho tea estates complex in Kenya. Unpublished Ph.D. thesis, University of Nairobi.

Ratha, D., 2007. Leveraging Remittances for Development. Policy Brief, Migration Policy Institute, Washington DC.

Singh, C., 2019. Migration as a driver of changing household structures: Implications for local livelihoods and adaptation. Migration and Development, 8, 301-319, https://doi.org/10.1080/21632324.2019.1589073

Suja, R., Letha, J., and Varghese, J., 2013. Evaluation of urban growth and expansion using Remote Sensing and GIS.
International Journal of Engineering Research \& Technology, 2(10), 2772-2779.

Trading Economics, 2019. Sudan Population. https://tradingeconomics.com/sudan/population-total-wbdata.html (accessed on 6 October, 2019).

United Nations, 2019. A world on the move - UN DESA reveals latest data on international migration. United Nations Department of Economic and Social Affairs (UN-DESA (https://www.un.org/development/desa/en/news/population /international-migration-2.html) (accessed on 16 October, 2019).

UNSECO, 2019. Gender parity index (GPI). http://uis.unesco.org/en/glossary-term/gender-parity-indexgpi (accessed on 29 October, 2019).

UNICEF, 2019. Gender and education. https://data.unicef.org/topic/gender/gender-disparities-ineducation/ (accessed on 28 October, 2019).

Vago, S. , 2003. Social Change: Pearson Prentice Hall.

Whiteside, T. G., Boggs, G. S., \& Maier, S. W., 2011. Comparing object-based and pixel-based classifications for mapping savannas. International Journal of Applied Earth Observation and Geoinformation,13(6), 884-893. doi: 10.1016/j.jag.2011.06.008 /

Wikihow, 2019. How to Prevent Soil Erosion. https://www.wikihow.com/Prevent-Soil-Erosion (accessed on 19 October, 2019).

WHO, 2017. Guidelines for Drinking-water Quality. $4^{\text {th }}$ edition. World Health Organization.

World Population Review, 2019. Sudan Population 2019. http://worldpopulationreview.com/countries/sudanpopulation (accessed on 6 October, 2019).

Worldometers, 2019. Sudan Population https://www.worldometers.info/world-population/sudanpopulation/ (accessed on 7 October, 2019).

Yagoub, M. M., 2004. Monitoring of urban growth of a desert city through remote sensing: Al-Ain, UAE, between 1976 and 2000. International Journal of Remote Sensing, 25(6), 1063-1076. doi: 10.1080/0143116031000156792

Yan, G., Mas, J. - , Maathuis, B. H., Xiangmin, Z., \& Dijk, P. M., 2006. Comparison of pixel- based and object- oriented image classification approaches - a case study in a coal fire area, Wuda, Inner Mongolia, China. International Journal of Remote Sensing, 27(18), 4039-4055. doi: 10.1080/01431160600702632.

Zhang, Y., Paul Block, Michael Hammond, and Andrew King, 2015. Ethiopia's Grand Renaissance Dam: Implications for Downstream Riparian Countries. Journal of Water Resources Planning and Management, 14(9): https://ascelibrary.org/doi/abs/10.1061/\%28ASCE\%29WR. 1943-5452.0000520 (accessed on 17 October, 2019). 